\title{
Study on Countermeasures of the Self-management of Higher Vocational College Students
}

\author{
Xiaoyan Zhang \\ Xuzhou College of Industrial Technology, Jiangsu Xuzhou, China \\ 1595968094@qq.com
}

\begin{abstract}
Keywords: Higher vocational college students; Self-management; Countermeasure research; Self-planning
\end{abstract}

\begin{abstract}
Countermeasures and suggestions were put forward to enhance self-management of Higher Vocational College students from three aspects: individuals, families and schools based on investigating current situation and influential factors of the Self-management of Higher Vocational College Students. At the individual level, the Countermeasures cover subjective self-management and objective self-management. At the school level, the Countermeasures are to guide Vocational College Students' self-management, implement classified management of higher vocational students according to the different groups and create a good campus atmosphere. At the social level, the Countermeasures are to obtain family support and establish social self-discipline values.
\end{abstract}

\section{Introduction}

Self-management of Higher Vocational College students refers to, to achieve the training objectives of higher occupation education and meet the social requirements of individual quality, that the vocational college students, by mobilizing their initiatives, utilize and integrate their own resources (physical, psychological, time and thoughts, etc), furthermore, through scientific management methods, carry out activities of self-cognition, self-planning, self -coordination, self-motivation and self-control.[1-3] Many scholars studied college students' self -management from qualitative analysis angle. According to quantitative research on the students self-management, we have studied how to improve self-management of Higher Vocational College students from the school, society, individual and presented countermeasures and suggestions.

\section{Organization of the Text}

Investigation on the Present Situation of Self- Management of Higher Vocational College Students. In this paper, we investigated 10000 college students from 13 Vocational Colleges in China, and 6375 valid samples were obtained. Using Likert scale six point scoring method, we found that Higher Vocational College students' self-management means is 3.6704, which suggested that self-management of Higher Vocational College students is generally low. Further comparison of the five dimensions of self-management showed that the lowest is self-planning (3.3448), followed by self- cognition (3.4489) and self- control (3.6326). Each dimension score statistics of self-management is shown in Table 1.

Table 1 The general situation of self management

\begin{tabular}{llllll}
\hline factor & $\begin{array}{c}\text { sample } \\
\text { size }\end{array}$ & $\begin{array}{l}\text { minimu } \\
\mathrm{m}\end{array}$ & $\begin{array}{l}\text { maximu } \\
\mathrm{m}\end{array}$ & mean & $\begin{array}{l}\text { standard } \\
\text { deviatio } \\
\text { n }\end{array}$ \\
self- cognition & 6375 & 1.00 & 6.00 & 3.4489 & .95329 \\
self-planning & 6375 & 1.00 & 6.00 & 3.3448 & .99774 \\
self-coordination & 6375 & 1.00 & 6.00 & 3.9628 & .92022 \\
self-motivation & 6375 & 1.00 & 6.00 & 3.9627 & .90420 \\
self- control & 6375 & 1.00 & 6.00 & 3.6326 & .89216 \\
self-management & 6375 & 1.00 & 6.00 & 3.6704 & .76827 \\
\hline
\end{tabular}


Investigation on the Influencing Factors of Self-management of Higher Vocational College Students. In addition to individual background variables (gender, one-child, grade, subject categories, cultural degree of parents, etc)in literature research ,the influence factors of self-management involve school factors, social factors, individual factors, using interview method. Among them, school factors include training concept, teachers support, training mode and campus atmosphere; social factors include family support, social support, self-discipline; individual factors include personalities, self-esteem and achievements. Based on the interview, we used questionnaire to research all kinds of factors. By means of analyzing 6375 higher vocational college students from 13 Vocational Colleges in china, we firmly hold that the greatest impact on self-management is self-discipline, followed by self-esteem, and then family support. The order of School factors is Teacher support, training mode, training concept, campus atmosphere. The order of social factors is self discipline, family support and social support. The order of individual factors is the sense of self-esteem and achievements, personalities, The specific figures are shown in Table 2 .

Table 2 The influence factors of self management: the summary table ranking

\begin{tabular}{|c|c|c|c|c|c|c|c|c|}
\hline level & factor & $\begin{array}{l}\text { sample } \\
\text { size }\end{array}$ & $\begin{array}{l}\text { minim } \\
\text { um }\end{array}$ & $\begin{array}{l}\operatorname{maxim} \\
\text { um }\end{array}$ & mean & $\begin{array}{l}\text { standard } \\
\text { deviation }\end{array}$ & $\begin{array}{l}\text { Group } \\
\text { order }\end{array}$ & $\begin{array}{l}\text { Total } \\
\text { order }\end{array}$ \\
\hline \multirow{4}{*}{$\begin{array}{l}\text { scho } \\
\text { ol }\end{array}$} & training & 6375 & 1.00 & 6.00 & 3.6342 & 1.01357 & 3 & 8 \\
\hline & $\begin{array}{l}\text { concept } \\
\text { teachers } \\
\text { support }\end{array}$ & 6375 & 1.00 & 6.00 & 3.7507 & 1.05542 & 1 & 6 \\
\hline & $\begin{array}{l}\text { training } \\
\text { mode }\end{array}$ & 6375 & 1.00 & 6.00 & 3.6938 & 1.06658 & 2 & 7 \\
\hline & $\begin{array}{l}\text { campus } \\
\text { atmosphere }\end{array}$ & 6375 & 1.00 & 6.00 & 3.5849 & 1.05825 & 4 & 9 \\
\hline \multirow{3}{*}{$\begin{array}{l}\text { socie } \\
\text { ty }\end{array}$} & $\begin{array}{l}\text { family } \\
\text { support }\end{array}$ & 6375 & 1.00 & 6.00 & 4.0705 & 1.00250 & 2 & 3 \\
\hline & social & 6375 & 1.00 & 6.00 & 3.5317 & 1.05350 & 3 & 10 \\
\hline & $\begin{array}{l}\text { self-disciplin } \\
\mathrm{e}\end{array}$ & 6375 & 1.00 & 6.00 & 4.3221 & 1.02083 & 1 & 1 \\
\hline \multirow{3}{*}{$\begin{array}{l}\text { indiv } \\
\text { idual }\end{array}$} & personalities & 6375 & 1.00 & 6.00 & 3.9071 & 91055 & 3 & 5 \\
\hline & self-esteem & 6375 & 1.00 & 6.00 & 4.1764 & .91618 & 1 & 2 \\
\hline & achievement & 6375 & 1.00 & 6.00 & 4.0448 & .96964 & 2 & 4 \\
\hline
\end{tabular}

Countermeasures and Suggestions on Improving the Level of Self-management of Higher Vocational College Students. It is found that the social factors (including family), school factors and individual factors influence the self-management of Higher Vocational College students. Individual factors are the results presented by all influence. To improve the Higher Vocational College students' self-management, the entry of individual students should be the most appropriate. However, once the effect of individual self-intervention is poor, the external intervention is needed. Therefore, enhancing the students' self-management level should be started from the school, society and individual.

Countermeasures and Suggestions at the School Level. Self-management of Higher Vocational College Students. Compared with university students, the ability of college students' self-management is relatively low, Therefore, it is necessary for educators to guide the students scientifically and rationally to learn self-management. First, to help students to recognize themselves comprehensively and objectively. Educators should help the students learn who they are and what they will do by means of teacher' management, teaching process, and students' management. Second, to guide students to schedule themselves scientifically and rationally. That freshman participate in the career planning competition is a very good self-programming mode. Students should be required to plan their career in order to enhance the capability of self-planning. 
Third, to remind students to coordinate themselves timely. By mental health counseling, educators can guide and help students to deal with the puzzles in their growing up. And social activities also can enhance their understanding of the society and the ability to adapt to the society. Fourth, to teach students to effectively motivate themselves. To achieve the effect of self-motivation, educators can guide students to actively participate in various kinds of competitions to stimulate their competitive consciousness. Fifth, to supervise the students to strictly control themselves. Through the target management method, educators can guide the students to be self-control. Combining the goals of the individuals, schools, families and the society, educators can fully arouse the subjective initiative of students' self-management through assistance, guidance, lead, reminders, church, and supervision etc.

Classification management of Vocational College Students. Considering all kinds of factors such as teaching management resources, the current management of students in Higher Vocational Colleges is based on the management structure model of class and grade. It is difficult for this simple approach to benefit students' status and personality. Given different groups of college students, educators are supposed to use classification management, like: (1) grade management, (2) focuses on training the one-child students self-management; (3) the cultivation of liberal arts college students' self-management, (4) difference management onenrollment or recruiting class.

Creating a good campus atmosphere. The survey shows that the campus atmosphere has a certain influence on the students' self-management. Through the construction of school spirit and self-management platform, harmonious relationship between teachers and students, educators can create good campus atmosphere to promote college students' self-management. (1)establishment of College Students' self-management development center.. Let the students behave their initiative and initiative in the management of their own learning, life and other social affairs. College students' self-management development centre can found their regulatory organizations to carry out activities, including party and Youth League organization, student union, class committee and so on. Much attention should be paid to the organization of students, which can be guided by the full-time teacher. (2)construction of school spirit. The school spirit is a silent command, which can become a huge force of education, and gradually evolve as the excellent tradition. It can urge students to internalize the positive power. The school spirit is the concentrated expression of study, life, discipline and so on. Therefore, the construction of school spirit should be strengthened, and students should be encouraged to study by means of competition and scholarship, so a good learning atmosphere will be formed. (3) a good relationship between teachers and students. The survey shows that the cultivation of students has great effects on self-management, therefore, the establishment of a good relationship between teachers and students can promote the students' self-management. Thus, higher vocational teachers should do the following: first, the difference of ability should be respected. Compared to undergraduate students, the Higher Vocational College students' basis is poor, and the ability to accept knowledge is weak. Therefore, the teaching contents and methods should be targeted. Second, the needs of reasonable study, work and development of Higher Vocational College students should be contented. Educators should understand their ability and consciousness and provide students with the opportunity to demonstrate ability. Third, the correct guiding role of teachers in the education process. The democratic relationship between teachers and students should be established, which can gradually guide the students to establish awareness of self-cognition, self-planning, self-coordination, self -motivation and self-control, moreover, enable students to be independent in mind, learning, thinking, behavior and self-care ability.

Countermeasures and Suggestions at the Social Level. Family education for children. Higher Vocational College Students' parents should supervise and guide their children's self-management. By updating the educational concept, creating the democratic atmosphere, and setting a good example, they should teach their children to learn to manage themselves. Because students are affected by family and social surroundings in their growing up, and a lack of self management, it needs family and school together to solve the problem. Therefore, families should communicate with schools to guide students' self-management. Families should create democratic atmosphere for 
their children, which can make their children equally share family affairs, and benefit the exercise of their self-management. Teaching is more important than words, parents' behavior will affect their children's behavior. Therefore, parents should learn self-management, which can influence the children. In work, family and social life, parents plan to work, which can make children, work independently, and train their self-management.

Society creates a good atmosphere for self-management. Social values of self-discipline. There exist pluralistic values in the current society, which has not only positive but also negative effects on students--- hedonism and money worship have negative impacts on students, for example. It is the key stage for students to form their values, who are easily affected by the external information. Therefore, the society should carry forward the mainstream cultural values, strengthen self-management and regulate their own bad behavior. This is a part of the mainstream values.[4].Social practice is an effective way to improve students' self-management. Society should provide places that students can participate in. Now the school-enterprise cooperation is an effective way, through which students can understand society, especially know which type of skills are needed, furthermore, modify their own learning and life.

Countermeasures and Suggestions for Students. Higher Vocational College students should practice self-management, which is not only the subject of management, but also the object of management. As subject of the management, students should act as self-cognition, self-planning, self-adjustment, self-motivation, self-control, while they should manage their academic development, physical and mental health, social activities and resources development as the object of management. The former is the subjective factor of self-management, the latter is the objective factor of self management.

Self-management of subjective factors. The subjective factors of self-management means Higher Vocational College students is the subject of management, including fully playing their subjective initiative, comprehensively understanding themselves, scientifically planning themselves, timely coordinating themselves, effectively motivating themselves and consciously controlling themselves.

Self-cognition is the premise and foundation of self-management of Higher Vocational College students, namely the subjects of cognition understand their behaviors and characteristics, including personality characteristics, mental status, learning life, advantages and disadvantages, success and failure, and the surroundings they live. Vocational college students should be fully aware that though they can not attend university due to lack of knowledge, they can become useful talents for society by learning to acquire skills. Self- planning that is intended for their future on purpose is an important part of self-management, though which students can schedule their study, life and other issues, moreover, self-planning can make their behaviors organized, efficient. Self- coordination is an important link to ensure self-management. Higher Vocational College students should learn self-coordination in order that they can increase their comprehensive ability through the coordination of effective resources. They should coordinate their relationships between themselves and the environment to make their own development keep pace with the times. Self-motivation is the driving force of self-management, and it is an important part of self-behavior. Students often encounter difficulties and setbacks in learning and life, and in the sub consciousness people always choose to retreat. Self-motivation is the best way to avoid retreat, though which students make themselves move on. Self-control is also an important link to ensure the smooth self-management in the established direction of self-planning. By self-control, students can resist the temptation of external network and so on. Students should make rational use of network resources, control their emotions, and establish a good network of contacts. Correctly handling the relationship between learning and entertainment, they won't lose the right direction in the virtual network world.

Self-management of objective factors. Objective factors of self-management means students, as objects of self-managing, need to manage their current affairs. As study is the important task of students, therefore, students should manage academic development, physical and mental health, social activities and resources development.

Countermeasures of management of academic development is regularly to set learning and evaluation objectives, and exclude the interference of the surroundings, in order to achieve 
self-control and restraint. Countermeasures of physical and mental health management is to make exercise plans, develop good habits, learn to control emotions, and timely adjust mind. Countermeasures in the management of social activities is to participate in work-study, community service, volunteer service and other forms of social practice. During summer and winter holidays, with the help of family and friends, students can work in the enterprises to practice their social practical ability and interpersonal communication skills. Countermeasures of management of resource development is to make full use of school resources, obtain the relevant certificates, effectively use time.

\section{Summary}

In a word, by the school, social and individual level, Higher Vocational College students' self-management level will be enhanced, what' more, their general and professional ability will be improved accordingly, which can achieve the training goal of higher vocational education. If everyone learns self-management and promotes self-management, the society can form self-discipline out of heteronomy, social changes, which can promote the harmonious development of the society and the construction of social spiritual civilization, and is more conducive to the development of social politics, economy and culture. It helps realize the dream of a powerful country of human resources, make the country stand in the forest of the nations. Therefore, the countermeasures on Higher Vocational College students' self-management have certain social application values.

\section{References}

[1] Hongyan Li, Cailing Shao, Tao An. Research on the cultivation of College Students' self management [J]. Journal of Agricultural University of Hebei, 2008

[2] Manlin Li. Analysis of College Students' self management [J]. Journal of Zhejiang College of Education, 2007.

[3] Jingfei Shen. Discussion on how to improve college students' self management [J]. Technology Innovation Herald 2011, (24)231

[4] Yang Yan, Xiaoyan Lin, Yajie Wang, Meng Zhang. Investigation and Countermeasures of College Students' cognitive level of life sense in the context of the diversified social values [J]. Journal of Tianjin University, 2009,11:555-558

[5] Zhang xiaoyan. Empirical Study on the Self-management of Higher Vocational College Students, Computer [J].Intelligent Computing and Education Technology, 2014, 3

[6] CreerT,RenneC,Christian W.Behavioral contrbutions to rehabilitation and childhood asthma. Rehabilitation Literature.1976,37:226-232

[7] KateR.Lorig,Dr.P.H.andHalstedR.Holman,M.D.Self-MangementEducation:History,Definition, Outcoms, andMechanisms[J].AnnalsofBehavioral Medicine,2003,(26):127.Bilsker

[8] Bilsker D, Goldner E M, Jones W. Health Service Patterns Indicate Potential Benefit of Supported Self-Management for Depression in Primary Care. Health Service Patterns Indicate Potential Benefit of Supported Self-Management for Depression in Primary Care. Canadian Journal of Psychiatry,2007, 52(2): 86 95

[9] Suk-hyang L, Simpson R L, Shogren K A. Effects and Implications of Self-Management for Students with Autism: A Meta-Analysis. Focus on Autism \& Other Developmental Disabilities, 2007, 22(1): 2 13,

[10] Schunk D H, Zimmerman B J. Influencing Children's Self-Efficacy and Self-Regulation of Reading and Writing Through Modeling. Reading \& Writing Quarterly, 2007, 23(1):7-25 